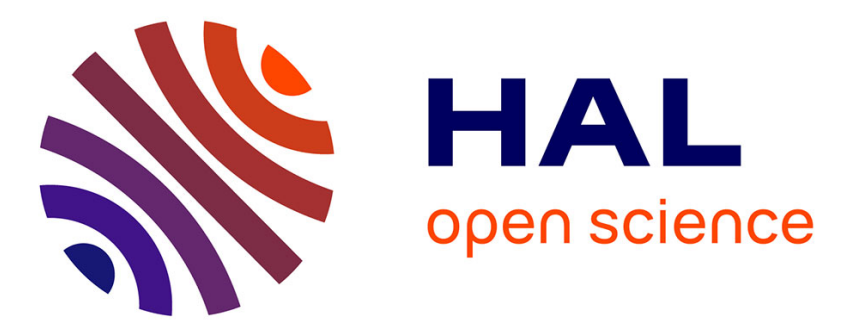

\title{
Numerical investigation of temperature and forming rate effect on AA5086 warm formability
}

Cunsheng Zhang, Guoqun Zhao, Hao Chen, Lionel Leotoing

\section{To cite this version:}

Cunsheng Zhang, Guoqun Zhao, Hao Chen, Lionel Leotoing. Numerical investigation of temperature and forming rate effect on AA5086 warm formability. 7th International Forum on Advanced Material Science and Technology, Jun 2010, Dalian, China. pp.607-610. hal-00979407

\section{HAL Id: hal-00979407 https://hal.science/hal-00979407}

Submitted on 15 Apr 2014

HAL is a multi-disciplinary open access archive for the deposit and dissemination of scientific research documents, whether they are published or not. The documents may come from teaching and research institutions in France or abroad, or from public or private research centers.
L'archive ouverte pluridisciplinaire $\mathbf{H A L}$, est destinée au dépôt et à la diffusion de documents scientifiques de niveau recherche, publiés ou non, émanant des établissements d'enseignement et de recherche français ou étrangers, des laboratoires publics ou privés. 


\title{
Numerical investigation of temperature and forming rate effect on AA5086 warm formability
}

Cunsheng ZHANG ${ }^{1 \mathrm{a}}$, Guoqun ZHAO ${ }^{1 \mathrm{~b}}$, Hao $\mathrm{CHEN}^{1 \mathrm{c}}$, Lionel LEOTOING ${ }^{2 \mathrm{~d}}$

${ }^{1}$ Key Laboratory for Liquid-Solid Structural Evolution and Processing of Materials (Ministry of Education), Shandong University, Jinan, Shandong Province 250061, P.R.China

Université Européenne de Bretagne, INSA-LGCGM, EA 3913, 20 avenue des Buttes de Coësmes, 35043 Rennes Cédex, France

azhangcs@sdu.edu.cn, brhaogq@sdu.edu.cn

\section{Keywords: Forming Limit Diagrams (FLDs); Marciniak test; Warm formability; UHARD subroutine}

\begin{abstract}
The poor formability of aluminum alloy at room temperature limits its use in some products with complex shapes, hence the warm forming process is intended to overcome this problem by using an elevated temperature. Now, the warm formability of AA5086 has not previously been well investigated in the literatures, especially at a rapid forming rate. In this paper, a numerical method has been developed to investigate the warm formability of an AA5086 sheet. Firstly, the dynamic tensile test was carried out under different forming temperatures and forming rates to identify an appropriate constitutive law for the sheet. The inverse analysis was performed to identify the parameter values in the constitutive law. Then based on the commercial finite element program ABAQUS, the Marciniak test was simulated to evaluate the sheet formability of by implementing a user-defined material subroutine UHARD. The effects of forming temperature and forming rate on sheet formability were investigated and it is shown that the formability of AA5086 seems to be insensitive to the forming temperature and forming rate.
\end{abstract}

\section{Introduction}

Due to its advantage of high-strength to weight ratio, high strength and corrosion resistance, aluminum alloy is becoming one of the main materials to replace steel in order to reduce weight. It is reported that between 1995 and 2000, the use of aluminum has increased by over 80\% in automotive applications [1]. However, aluminum alloy shows the poor formability at room temperature compared to steels. Hence, the warm forming process is intended to overcome this problem by using an elevated forming temperature which is below the recrystallization temperature [2-3].

For sheet metal forming, FLDs, which proposed by Keeler and Backofen in 1960s [4], are an efficient diagnostic tool for evaluating sheet formability and many methods have been developed to determine the FLDs [5-7]. For experimental predictions of FLDs, two main kinds of forming tests have been developed, the so-called out-of-plane stretching and the in-plane stretching. However, it is a very timeconsuming procedure to establish FLDs and the scatter in experimental data for a given sheet is usually large [8]. As a result, significant efforts have been made on developing more analytical or numerical models for construction of FLDs. Using the LDH (Limiting Dome Height) test, Narasimhan [9] has predicted the onset of localized necking by calculating the thickness strain gradient across neighboring regions. With the Marciniak test, Petek et al. [5] proposed that the maximum of the second temporal derivative of the thickness strain corresponds to the onset of localized necking. Volk [10] identified the onset of localized necking by the two following main effects: increase of point number with high strain rate (in the localization region) and decrease of the strain rate outside the localization bands.

Aluminum alloy 5086 (AA5086) is a medium to high strength alloy, which is commonly used in the manufacture of unfired, welded pressure vessels, marine, auto aircraft cryogenics, etc. However, little 
attention has been put on the warm forming behavior and sheet formability for this alloy, especially for a rapid forming rate. Hence, the paper begins with the dynamic tensile test for an AA5086 sheet. An inverse analysis will be applied to identify warm forming behaviors of this aluminum sheet and the corresponding parameters in the constitutive law will be determined. Furthermore, with commercially available finite-element program ABAQUS, the FE model based on the Marciniak test will be developed and simulated to investigate numerically the warm formability of AA5086. And the effects of forming temperature and forming rate on the sheet formability will be investigated.

\section{Determination of material constitutive laws}

The tensile test is carried out on a computer-controlled servo-hydraulic testing machine under different forming temperatures $\left(20,230,290,350^{\circ} \mathrm{C}\right)$ and forming rates $(10,750,1000 \mathrm{~mm} / \mathrm{s})$. At high temperatures, the mechanical behavior of aluminum alloys results from a balance between workhardening and thermal softening. This behavior can be represented by the use of a modified Voce's hardening law ([11-12]) (Eq.1)

$$
\bar{\sigma}=\sigma_{0}+C_{1} \sqrt{1-e^{-n(T) \bar{\varepsilon}}} e^{\left(\frac{C_{4}}{T}\right)} \dot{\bar{\varepsilon}}^{m(T)}
$$

Where $\bar{\sigma}$ and $\bar{\varepsilon}$ are the equivalent plastic stress and strain, respectively, and $\sigma_{0}$ the yield strength. The indexes $n$ and $m$ are the function of forming temperature $T$ :

$$
n(T)=C_{2} e^{\left(C_{3} T\right)} \text { and } m(T)=C_{5}+C_{6} T
$$

The coefficients $C_{i}(i=1 \sim 6)$ are constants, they are identified by the inverse analysis procedure, which has been described in detail in author's previous paper [13]. It is supposed that the value of the yield strength depends only on temperature but not on strain rate level, which is commonly verified for aluminum alloys [14]. The yield strengths and the identified constitutive parameters $C_{i}$ at 20, 230, 290 and $350^{\circ} \mathrm{C}$ are given in Table 1.

Table 1: Yield strengths and constitutive parameter values.

\begin{tabular}{lcccc} 
& $20^{\circ} \mathrm{C}$ & $230^{\circ} \mathrm{C}$ & $290^{\circ} \mathrm{C}$ & $350^{\circ} \mathrm{C}$ \\
\hline$\sigma_{0}(M P a)$ & 162.7 & 147.2 & 131.7 & 116.2 \\
$C_{1}(M P a)$ & & 27.41 & \\
$C_{2}$ & \multicolumn{4}{c}{1.76} \\
$C_{3}\left(K^{-1}\right)$ & \multicolumn{4}{c}{$2.08 \times 10^{-3}$} \\
$C_{4}(K)$ & \multicolumn{4}{c}{606.20} \\
$C_{5}$ & \multicolumn{4}{c}{$-1 \times 10^{-6}$} \\
$C_{6}\left(K^{-1}\right)$ & & $1.54 \times 10^{-4}$ \\
\hline
\end{tabular}

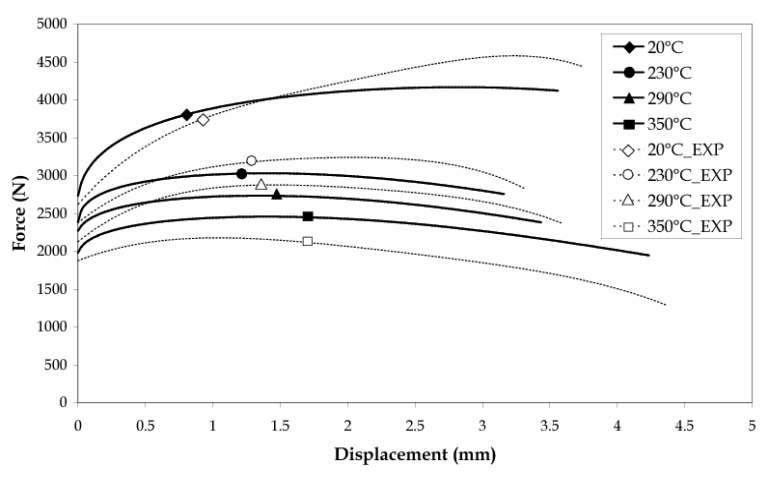

Fig. 1 Comparison of experimental and identified load-displacement curves at $10 \mathrm{~mm} / \mathrm{s}$

The comparison between experimental and identified loads versus displacement at $10 \mathrm{~mm} / \mathrm{s}$ is illustrated in Fig.1. The agreement between the experimental curves and the ones identified by inverse analysis is not perfect but the Voce's constitutive law and the identified parameters permit to well model the global effect of temperature and strain rate on the behavior of this aluminum alloy. Considering self-heating, thermal radiation and conductivity, not presented in this work, should improve the identification of the parameters.

\section{Numerical determination of FLDs with the Marciniak test}




\subsection{FE model}

In this part, the Marciniak test is modeled with the ABAQUS to evaluate the AA5086 sheet formability. The FE model of the Marciniak test consists of three parts: a rigid cylindrical punch with a flat bottom, a die and a deformable sheet. In addition, a pressure load is directly applied on the sheet as the blank-holder force (Fig.2). Keeping the blank in place by means of pressure and friction will be used also in the future experiments.

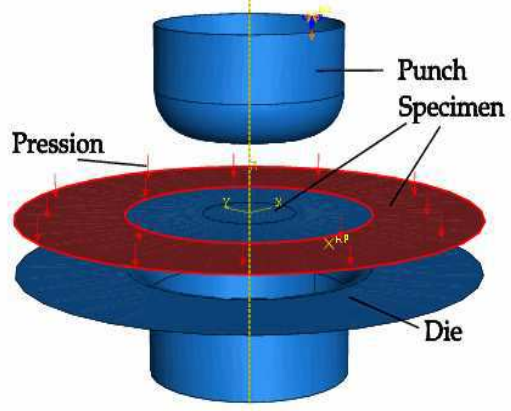

Fig. 2 FE model of the Marciniak test

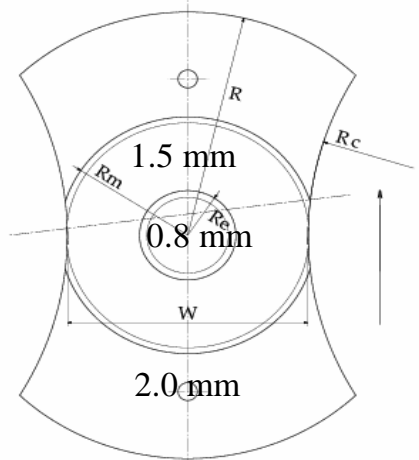

Fig.3 Geometry of Marciniak specimen

The Marciniak test requires the application of different specimen geometries to cover different strain states, ranging from uniaxial through plane strain to equi-biaxial stretching. In this work, all test samples are shaped by cutting strips of different widths $\mathrm{W}$ in a circular flange, according to Fig.3. To assure the occurrence of the maximal strains (to trigger localization) on the central part of the blank, the specimens are designed with a reduced central thickness $(0.8 \mathrm{~mm})$ compared to the thickness of adjoining part $(1.5 \mathrm{~mm})$ and the clamping part with a thickness of $2.0 \mathrm{~mm}$.

The model is meshed with shell linear elements S4R. The elasticity of the specimen is defined with a Young's modulus of $67000 \mathrm{MPa}$ and a Poisson's ratio of 0.3 . The constitutive law (1) is implemented into ABAQUS by using the UHARD user subroutine. During the simulation, the die is fixed and the punch moves downwards at different speeds, where the forming rates correspond to the above dynamic tensile test. The contact interactions between the surfaces of the FE model are defined with Coulomb's friction law. The friction coefficients between punch and parts with thicknesses of $1.5 \mathrm{~mm}$, and $2.0 \mathrm{~mm}$ are 0.05 and 0.1 , respectively. There is no friction between the punch and the central part of specimen, which is under the identical condition to the future experimental procedure.

\subsection{Determination of localized necking}

Here, a failure criterion, widely used in the M-K model, is applied to determine the onset of localized necking. When the ratio of equivalent plastic strain increment in localized element and its adjacent one on the blank reaches 7, the major and minor strains in the adjacent element are noted as limit strains. The same procedure is repeated for all specimens and the corresponding limit strains describe the forming limit curve. With the above failure criterion, the FLDs under different temperatures (20, 230, $\left.290^{\circ} \mathrm{C}\right)$ and forming rates $(10,750,1000 \mathrm{~mm} / \mathrm{s})$ are determined. The comparisons of FLDs at a given forming rate of $10 \mathrm{~mm} / \mathrm{s}$ and those at a given forming temperature of $230^{\circ} \mathrm{C}$ are shown in Fig. 4 and Fig.5, respectively. From these figures, the general shape of FLDs is observed, and the minimal formability occurs under the plane strain condition. In addition, the numerical results show that the sheet formability of AA5086 seems to be insensitive to forming temperature and forming rate, which do not completely agree with the conclusion for other aluminum alloys in the literatures [2-3]. However, the method proposed in this work permits to numerically evaluate the sheet formability. These results must be experimentally validated in order to determine accurate FLDs necessary and optimize the warm forming processes. This validation is in progress by means of a dynamic Marciniak test associated with a high-speed camera and the digital image correlation (DIC) technique to detect the onset of localized necking and construct FLDs. 


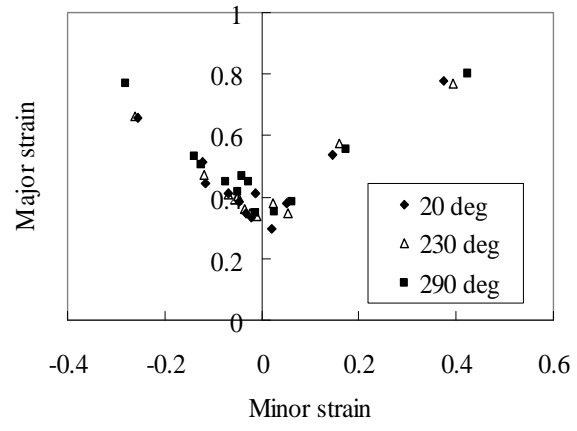

Fig.4 Comparison of FLDs at $10 \mathrm{~mm} / \mathrm{s}$

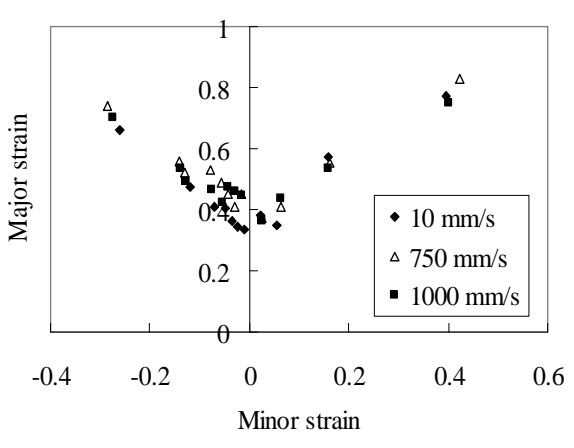

Fig.5 Comparison of FLDs at 230 degree

\section{Conclusion}

In this paper, the warm forming behavior of AA5086 is investigated by experimental and numerical methods. A modified Voce's law was identified by the inverse analysis to describe its high temperature forming behavior. By means of a user-defined material subroutine UHARD, the material's constitutive law was implanted into ABAQUS and the Marciniak test was simulated to evaluate the sheet formability. The effects of forming temperature and forming rate on AA5086 sheet formability were also investigated. Numerical results show that the formability of this alloy seems to be insensitive to forming temperature and forming rate. This experimental validation of these results is in progress by means of a dynamic Marciniak test.

\section{References}

[1] W.S. Miller, L. Zhuang, J. Bottema et al. Materials Science and Engineering A Vol.280:37-49, 2000.

[2] S. Toros, F. Ozturk, and I. Kacar. Journal of Materials Processing Technology Vol.207:1-12, 2008.

[3] D.M. Li and A.K. Ghosh. Journal of Materials Processing Technology Vol.145:281-293, 2004.

[4] S.P. Keeler and W.A. Backofen. Trans. ASM Vol.56:25-48, 1963.

[5] A. Petek, T. Pepelnjak, and K. Kuzman. Journal of Mechanical Engineering Vol.51:330-345, 2005.

[6] H.B. Campos, M.C. Butuc, and J.J. Gracio. Journal of Materials Processing Technology Vol.179:56-60, 2006.

[7] P. Eyckens, A. Van Bael, and P. Van Houtte. International Journal of Plasticity Vol.25:2249-2268, 2009.

[8] P.D.Wu, S.R. MacEwen, D.J. Lloyd, and K.W. Neale. Modelling and Simulation in Materials Science and Engineering Vol.12:511-527, 2004.

[9] K. Narasimhan. Proceedings of the 8th International Conference on Numerical Methods in Industrial Forming Processes, 2:850-855, 2004.

[10] W. Volk. Proceedings of the FLC-Zurich 06, Zurich, Switzerland, 2006.

[11] P. Lukac. Aluminium Alloys - Materials Science Forum Vol.217-222:71-82, 1996.

[12] S. Diot, D. Guines, A. Gavrus and E. Ragneau. International Journal of Forming Processes Vol.9:167-188, 2006.

[13] C.S. Zhang, L. Leotoing, D. Guines et al. Materials Science and Engineering: A Vol.527:967-972, 2010

[14] K.O. Pedersen, H.J. Roven, O.G. Lademo et al. Microstructure and Processing Vol.473:281-289, 2008. 